Izabela Śliwińska-Słomska

Uniwersytet Warszawski

ORCID ID: 0000-0001-9875-4772
OBLICZA WOJNY

TOM $5 \cdot$ MIASTO I WOJNA

ŁÓDŹ 2021 • ISBN 978-83-8220-699-9 • s. 75-87

https://doi.org/10.18778/8220-699-9.05

\title{
SYTUACJA WEWNĘTRZNA W KAMIEŃCU PODOLSKIM W LECIE 1648 ROKU W KORESPONDENCJI SĘDZIEGO ZIEMSKIEGO PODOLSKIEGO ŁUKASZA MIASKOWSKIEGO
}

\begin{abstract}
Streszczenie. Łukasz Miaskowski, sędzia ziemski podolski oraz marszałek sądu kapturowego, w trakcie bezkrólewia po śmierci Władysława IV przebywał latem 1648 r. w Kamieńcu Podolskim. Ze względu na rozległe kontakty z elitą Hospodarstwa Mołdawskiego pozyskiwał on, segregował i przekazywał elitom Rzeczypospolitej informacje o bieżących wydarzeniach w księstwach naddunajskich, ruchach wojsk tatarskich czy też sytuacji wewnętrznej w Porcie Otomańskiej. W lecie 1648 r., a więc w pierwszym okresie powstania Bohdana Chmielnickiego, donosił również o postępach w ofensywie wojsk kozackich, nastrojach panujących wśród wiejskiej ludności Podola i ziem ukrainnych oraz o sytuacji wewnętrznej Kamieńca Podolskiego. Zawarta w artykule analiza źródeł ukazuje stan techniczny twierdzy, liczebność jej załogi oraz czynniki wpływające na morale jej obrońców, takie jak obawa przed atakiem ze strony Kozaków i Tatarów oraz strach przed zdradą ze strony przebywających w mieście Rusinów. Wśród adresatów korespondencji $Ł$. Miaskowskiego byli: kanclerz Jerzy Ossoliński, chorąży koronny Aleksander Koniecpolski, pisarz polny koronny Adam Hieronim Sieniawski czy podkomorzy Iwowski, a zarazem brat nadawcy Wojciech Miaskowski.
\end{abstract}

Słowa kluczowe: Kamieniec Podolski, powstanie Chmielnickiego, oblężenie, Łukasz Miaskowski, Kozacy

Twierdza w Kamieńcu Podolskim za sprawą literatury oraz dzieł kultury wpisała się w świadomość kulturową oraz historyczną Polaków. Zanim jednak stała się symbolem, odgrywała dużą rolę w potencjale obronnym Rzeczypospolitej jako właściwie jedyne na tym kierunku działań zbrojnych założenie obronne, 
ochraniające południowo-wschodnie kresy państwa polsko-litewskiego ${ }^{1}$. Do największych atutów obronnych Kamieńca Podolskiego zaliczało się z pewnością jego położenie. Historyczne miasto otoczone jest niemal w całości płynącą w głębokim jarze rzeką Smotrycz, a w miejscu, gdzie rzeka daje dostęp do miasta, jeszcze w średniowieczu wybudowano pierwszą twierdzę, nazywaną później Starym Zamkiem². W latach dwudziestych XVII w. w obliczu rosnących napięć między Rzeczpospolitą a Turcją wzmocniono obwarowania, dobudowując od zachodu bastionowe dzieło rogowe umocnione dwoma półbastionami z orylonami. Budowę tych umocnień, zwanych Nowym Zamkiem, zainicjował król Zygmunt III, dla którego była to realizacja pacta conventa ${ }^{3}$.

Liczebność załogi twierdzy kamienieckiej zmieniała się w przeciągu wieków. Sejmy z lat 1580-1581 uchwaliły jej wysokość na 100 żołnierzy piechoty oraz zaprzysiężonego rotmistrza ${ }^{4}$. W późniejszym okresie załoga Kamieńca Podolskiego powiększona została do 200 piechurów ${ }^{5}$. Skład narodowościowy garnizonu prawdopodobnie odzwierciedlał strukturę etniczną samego miasta i jego okolic, zamieszkałych przeważnie przez Rusinów, skoro w konstytucji uchwalonej na sejmie obradującym na przełomie 1649 i 1650 r. zalecono, aby załoga składała się z „niemieckiego lub polskiego narodu”, nie zaś „z tamecznych mieszczan

1 Szerszy obraz specyfiki miasta i regionu ukazany został w zbiorowych publikacjach pod redakcją Feliksa Kiryka: Kamieniec Podolski. Studia z dziejów miasta i regionu, t. 1, red. F. KIRYK, Kraków 2000; Kamieniec Podolski. Studia z dziejów miasta i regionu, t. 2, red. F. KIRYK, Kraków 2005; a także w: R. Król-MaZur, Miasto trzech nacji. Studia z dziejów Kamieńca Podolskiego w XVIII wieku, Kraków 2008. Problematyka związana z zagadnieniami kartograficznymi vide: L. OPRYCHAE, Rękopiśmienne plany i ryciny twierdzy Kamieniec Podolski, Warszawa 2019; IDEM, Plany Kamieńca Podolskiego w bibliotekach i archiwach swiata, „Kwartalnik Historii Nauki i Techniki” 2016, R. 61 (2), s. 89-110. Kwestie związane z funkcjonowaniem garnizonu w Kamieńcu Podolskim przed wojną z Imperium Osmańskim vide: Z. HunderT, Garnizon wojskowy Kamieńca Podolskiego w latach 1668-1672, „Saeculum Christianum” 2014, t. 21, s. 141-153. Opis panowania tureckiego w Kamieńcu Podolskim vide: D. KoŁodZIEJCZYK, Podole pod panowaniem tureckim. Ejalet kamieniecki 1672-1699, Warszawa 1994; znaczenie Kamieńca Podolskiego dla obronności nowożytnej Rzeczypospolitej w XVIII w. vide: T.M. NowAK, Twierdza Kamieniec Podolski w XVIII w. na tle polskiej fortyfikacji na ziemiach zagrożonych najazdami Turków i Tatarów, „Fortyfikacja” 1995, t. 1, s. 25-36; IDEM, Fortyfikacje i artyleria Kamieńca Podolskiego w XVIII w., „Studia i Materiały do Historii Wojskowości" 1973, t. 19, s. 139-186.

2 B. DYвAŚ, Fortece Rzeczypospolitej. Studium z dziejów budowy fortyfikacji statych w państwie polsko-litewskim wXVII wieku, Toruń 2018, s. 207.

${ }^{3}$ Ibidem, s. 208.

${ }^{4}$ Volumina Legum (dalej: VL), t. 2, wyd. J. OHRYZKo, Petersburg 1859, s. 219.

5 B. DyBAŚ, op. cit., s. 429. 
albo rzemieślników”6. W 1649 r. założono również w twierdzy kamienieckiej jeden $\mathrm{z}$ arsenałów artylerii koronnej ${ }^{7}$.

Przyczyn tak daleko idących zmian można upatrywać m.in. w sytuacji wewnętrznej Kamieńca Podolskiego w 1648 r., a więc w pierwszym okresie powstania Bohdana Chmielnickiego. Do jednej z najbardziej wszechstronnych (choć niepozbawionej pewnej dozy subiektywizmu) relacji z tamtego okresu należy korespondencja sędziego podolskiego Łukasza Miaskowskiego, przebywającego w tamtym czasie w mieście. Późniejszy sędzia podolski wywodził się z osiadłej w Wielkopolsce rodziny średniozamożnej szlachty pieczętującej się herbem Leliwa, jednak większość swego życia spędził na Podolu. Początki jego kariery związane są z osobą hetmana wielkiego koronnego Stanisława Żółkiewskiego, którego był sekretarzem. W 1620 r. walczył pod Cecorą, czego dowodem jest napisany przez niego opis początkowej fazy tego $\operatorname{starcia}^{8}$. Po przegranej batalii Ł. Miaskowski, jak wielu innych, został wzięty do trwającej trzy lata niewoli tureckiej, z której uwolniony został najprawdopodobniej dzięki staraniom Krzysztofa Zbaraskiego9. Nie jest wykluczone, że przymusowy pobyt w Turcji umożliwił Ł. Miaskowskiemu poznanie języków orientalnych, obyczajów oraz tamtejszego kodu kulturowego ${ }^{10}$. Po śmierci wcześniejszego patrona Ł. Miaskowski został zaufanym klientem Stanisława Koniecpolskiego i w imieniu hetmana prowadził działania wywiadowcze na terytorium Imperium Osmańskiego ${ }^{11}$. Późniejszy sędzia podolski u boku S. Koniecpolskiego brał udział w bitwie pod Hamersztynem oraz w starciu z Tatarami pod Martynowem, czego dowodem są spisane przez niego relacje z tych zmagań ${ }^{12}$.

${ }^{6}$ Ibidem, s. 194; vide: VL, t. 4, wyd. J. OHRYZKo, Petersburg 1859, s. 131.

7 T.M. NowaK, Polska artyleria, inżynieria i kartografia wojskowa w XVII wieku, „Studia i Materiały do Historii Wojskowości” 1979, t. 22, s. 89.

${ }^{8}$ Biblioteka ks. Czartoryskich w Krakowie (dalej: B.Czart.), Korespondencja Łukasza Miaskowskiego z obozu pod Cecorą, rkps 1577, k. 433-437.

9 A.A. Witusik, Korespondencja jeńców cecorskich, „Rocznik Lubelski” 1987-1988, R. 29-30, s. 109-110.

${ }_{10}$ IDEM, Miaskowski Eukasz Kazimierz h. Leliwa, [w:] Polski Stownik Biograficzny, 1975, t. 20, z. 86 , s. 544 .

${ }^{11}$ Korespondencja Stanistawa Koniecpolskiego, hetmana wielkiego koronnego, red. A. BIEDRZYCKA, Kraków 2005, s. 219-229, 237-239, 249-251.

${ }^{12}$ Ł. MiaskowsKi, Rosprawa Jaśnie Wielmożnego Pana J. Mści P. Stanistawa z Koniecpola Koniecpolskiego, Woiewody Sendomirskiego, Hetmana Koronnego, etc, etc, z Woyjskiem Xiążecia Sudermańskiego Gustawa pod Amerstynem, w R. P. 1627, d. 17 kwietnia, Warszawa 1627; IDEM, Diariusz prawdziwy zwycięstwa nad Tatarami, [w:] Pamiętniki o Koniecpolskich, wyd. S. PRZYŁĘCKI, Lwów 1842, s. 255. 
Być może dzięki protekcji hetmańskiej Ł. Miaskowskiemu udało się uzyskać urzędy ziemskie. Były to kolejno godności: podstolego ${ }^{13}$, podsędka ${ }^{14}$ oraz sędziego ziemskiego podolskiego ${ }^{15}$. Jako przedstawiciel szlachty podolskiej posłował na sejmy oraz był deputatem do Trybunału Skarbowego w Radomiu. W trakcie bezkrólewia po śmierci króla Władysława IV Wazy pełnił funkcję marszałka kapturu podolskiego.

Łukasz Miaskowski dzięki zdobytej w niewoli znajomości obyczajów orientalnych oraz siatce informatorów pozyskiwał i rozsyłał dalej informacje o sytuacji na południowo-wschodniej granicy Rzeczypospolitej, w Porcie, na Krymie oraz w Księstwach Naddunajskich. W okresie powstania Chmielnickiego, jak i wcześniej, prowadził obszerną korespondencję z hospodarem mołdawskim Bazylim Lupulem ${ }^{16}$. Wśród odbiorców jego relacji byli m.in. Jan Żółkiewski, Mikołaj Potocki czy Andrzej Leszczyński. W trakcie początkowego okresu powstania Chmielnickiego Ł. Miaskowski kontynuował swoją działalność polegającą na dostarczaniu informacji elitom państwa polsko-litewskiego. Po przegranej bitwie pod Korsuniem sędzia podolski dzielił się ze swoimi korespondentami doniesieniami o sytuacji i stanie zdrowia przebywających w niewoli hetmanów. Dodatkowo informował także o rozwoju prokozackich nastrojów na Podolu, postępach w powstańczej ofensywie na Ukrainie, czy też planowanych działaniach Tatarów. Łukasz Miaskowski był również autorem jednego z opisów zdobycia Baru przez wojska pułkownika czerkaskiego Maksyma Krzywonosa ${ }^{17}$. Sędzia podolski pozyskiwał informacje z wielu źródeł. Były to doniesienia zdobyte dzięki siatce informatorów, wieści uzyskane od dostojników hospodarstwa mołdawskiego, relacje z podjazdów oraz zeznania jeńców. Informacje o sytuacji wewnętrznej Kamieńca Podolskiego przekazywane były równolegle $\mathrm{z}$ innymi doniesieniami. Łukasz Miaskowski opisywał własne odczucia, spostrzeżenia i obawy, co może rodzić pewne trudności interpretacyjne i wymaga uważniejszej krytyki źródłowej.

13 Urzędnicy podolscy XIV-XVIII wieku: spisy, red. A. GĄSIOROwsKI, Kórnik 1998, s. 103.

${ }^{14}$ Ibidem, s. 100.

15 Ibidem, s. 109.

${ }^{16}$ Vide: Documente privitoare la istoria Romanei culnese din arbivele polone. Secoul al XVII-lea, red. I. CORFUS, Bukareszt 1983, s. 162.

${ }^{17}$ Lwowska Narodowa Naukowa Biblioteka im. Stefanyka (dalej: LNNB), Z Kamieńca do JMCi Pana chorążego koronnego, 12 VIII 1648, fond 5, rkps 225, k. 124; LNNB, Copia listu JMP Łukasza Miaskowskiego sędziego podolskiego do JM Pana podkomorzego lwowskiego, 15 VIII 1648, fond 5 , rkps 225, k. 128-129v. 
Bazą źródłową odzwierciedlającą sytuację wewnętrzną Kamieńca Podolskiego latem i jesienią 1648 r. jest zbiór listów sędziego podolskiego do brata, podkomorzego lwowskiego Wojciecha Miaskowskiego oraz do dygnitarzy. Zostały one napisane w okresie od 4 lipca do 20 sierpnia tego roku. Większość korespondencji pochodzi z anonimowego, rękopiśmiennego kodeksu spisanego prawdopodobnie w XVII w., znajdującego się obecnie w zbiorach Lwowskiej Narodowej Naukowej Biblioteki im. Wasyla Stefanyka we Lwowie. Korespondencję Ł. Miaskowskiego odnaleźć można także w Tekach Michałowskiego. Część z listów wydana została w edycjach źródłowych przygotowanych zarówno przez badaczy polskich, jak i ukraińskich ${ }^{18}$. Co ciekawe, o skali szerokiego odbioru korespondencji Łukasza Miaskowskiego wśród ówczesnej opinii publicznej świadczy również fakt, że część listów odnaleźć można w dziale rękopisów Biblioteki ks. Czartoryskich w Krakowie ${ }^{19}$ i w Zbiorze Rusieckich, znajdującym się w zasobie archiwalnym Archiwum Narodowego w Krakowie ${ }^{20}$.

Analiza korespondencji Ł. Miaskowskiego umożliwia przedstawienie pięciu aspektów obrazujących sytuację wewnętrzną i nastroje obrońców Kamieńca Podolskiego w lecie $1648 \mathrm{r}$. Są to informacje dotyczące: stanu zachowania i procesu naprawiania umocnień, a także liczebności załogi oraz stanu zaopatrzenia garnizonu w artylerię, proch i amunicję. Na morale broniących twierdzy wpływały również czynniki niematerialne, takie jak świadomość ewentualnej zdrady ze strony przebywających w mieście Rusinów, strach przed nadciągającą kozacką ofensywą oraz obawa przed włączeniem się do działań wojennych wojsk tatarskich. W korespondencji kierowanej do różnych autorów, co mogło w oczywisty sposób wpływać na przedstawienie sytuacji wewnętrznej Kamieńca Podolskiego, niemal wszystkie te elementy się przeplatają.

Pierwsze informacje o stanie twierdzy kamienieckiej oraz liczebności i wyposażeniu jej załogi pojawiają się w liście sędziego podolskiego z 4 lipca $1648 \mathrm{r}$. adresowanym do kanclerza Jerzego Ossolińskiego ${ }^{21}$. Łukasz Miaskowski na

${ }_{18}$ Jakuba Michatowskiego, wojskiego lubelskiego a póżniej kasztelana bieckiego ksiega pamiętnicza, red. A. HelCel, Kraków 1864; Dżereta z istoriji Nacional'no-wyzwol'noji wijny ukrajins'koho narodu, t. 1, wyd. J. Мүсүк, Kijów 2011.

19 B.Czart., Copia listu od p. Miaskowskiego, sędziego podolskiego, z Kamieńca, 20 VIII 1648, rkps 379, k. 69.

20 Archiwum Narodowe w Krakowie, Zbiór Rusieckich, rkps 41, k. 177.

${ }^{21}$ D. Milewski, Rywalizacja polsko-kozacka o Motdawię w dobie powstania Bohdana Chmielnickiego (1648-1653), Zabrze 2011, s. 45; K. SZAjNocha, Dwa lata dziejów naszych 1646-1648, t. 2: Polska wr. 1648, Lwów 1869, nr 35, s. 359. 
marginesie doniesień o działaniach tatarskich przytoczył również dość interesującą informacjęo liczbie przebywających w twierdzy obrońców. Według nadawcy: „moribus antiquis po pięciu dziadów w bramie stawa i oprócz sta piechoty teraz zebranej, żadnego nie mamy subsydium"22. W dalszej korespondencji z 15 sierpnia 1648 r. sędzia podolski wspomniał również o „dawnej” załodze Kamieńca Podolskiego liczącej 200 żołnierzy piechoty ${ }^{23}$. Zapis ten koresponduje z konstytucją z 1613 r., która ustalała liczebność stacjonujących w twierdzy żołnierzy.

Kolejne zapisy powiązane z kwestią możliwości przeprowadzenia obrony twierdzy kamienieckiej pojawiają się w dalszej korespondencji, datowanej na drugą połowę sierpnia 1648 r. Z kolei w niedatowanym liście (z treści można wywnioskować, że powstał on przed 15 sierpnia tego roku) widnieją szersze informacje o posiłkach, jakie zostały skierowane do obrony Kamieńca Podolskiego. Według Ł. Miaskowskiego jeden z dowodzących garnizonem twierdzy, kasztelan halicki Stanisław Lanckoroński, do obrony twierdzy zaangażował:

miast piechoty, której mieliśmy byli z tutecznymi i z wybrańcami tysiąc, on przeciwko wszystkich zdaniu i potrzebie, czterysta lekkich kozaków z łukami i sto husarzów z swoich przyjaciol zaciągnął i lubo widzi, że błąd, że takiej wielkiej machiny nie mamy czym bronić, zwłaszcza Nowego Zamku, przecie tuendo errorem kopie się przed folwarkami z temi chorągiewkami ${ }^{24}$.

Decyzja ta wywołała wśród obrońców twierdzy kamienieckiej wiele kontrowersji, skoro Ł. Miaskowski w liście do brata z 15 sierpnia podaje w wątpliwość sensowność wykorzystania uzbrojonej w łuki i kopie jazdy ${ }^{25}$. Wspomniana wyżej inicjatywa Stanisława Lanckorońskiego mogła również doprowadzić do sporu ze starostą kamienieckim Piotrem Potockim ${ }^{26}$, który został jednak zażegnany przez Łukasza Miaskowskiego ${ }^{27}$. Dodatkowo w owym niedatowanym liście sę-

22 LNNB, Z Kamieńca 4 VII 1648, fond 5, rkps 225, k. 88v.

23 LNNB, Copia listu od JMP Łukasza Miaskowskiego sędziego podolskiego do JMP Wojciecha Miaskowskiego, podkomorzego lwowskiego, 15 VIII 1648, fond 5, rkps 225, k. 129.

${ }^{24}$ LNNB, Z Kamieńca od pewnej osoby, fond 5, rkps 225, k. 124.

25 LNNB, Copia listu od JMP Łukasza Miaskowskiego sędziego podolskiego do JMP Wojciecha Miaskowskiego, podkomorzego lwowskiego, 15 VIII 1648, fond 5, rkps 225, k. 129.

26 O udziale starosty kamienieckiego Piotra Potockiego w obronie Kamieńca Podolskiego w trakcie powstania Bohdana Chmielnickiego vide: M. NAGIELSKI, Piotr Potocki, wojewoda bractawski - Hektor kamieniecki, „Wieki Stare i Nowe” 2020, t. 15 (20), s. 44.

${ }_{27}$ LNNB, Z Kamieńca do JMCi Pana podkomorzego lwowskiego, 17 VIII 1648, fond 5, rkps 225, k. $124 \mathrm{v}$. 
dzia podolski wspomniał również o obietnicach przysłania posiłków, złożonych przez m.in. wojewodę podolskiego Stanisława Rewerę Potockiego ${ }^{28}$.

W datowanej na 15 i 17 sierpnia korespondencji wysłanej z Kamieńca Ł. Miaskowski informował brata o braku możliwości obrony twierdzy. Z listów wynika, że pomimo mobilizacji w Kamieńcu Podolskim przebywało zbyt mało żołnierzy, by skutecznie obsadzić wszystkie mury ${ }^{29}$. Według stów sędziego podolskiego siły obrońców były niewystarczające, żeby obsadzić Nowy Zamek ${ }^{30}$, który był szczególnie narażony na ostrzał artyleryjski ${ }^{31}$. W związku z tym, pomimo braku odpowiedniego przygotowania fortyfikacji, zadecydowano, by centrum obrony uczynić Stary Zamek ${ }^{32}$. Łukasz Miaskowski w swojej korespondencji zaznaczał ponadto, że oprócz niedostatków piechoty zdolnej obronić twierdzę w garnizonie nie było też amunicjij ${ }^{33}$ oraz artylerzystów ${ }^{34}$. Pozytywne dla obrońców podolskiej twierdzy zmiany musiały nastąpić między 18 i 20 sierpnia 1648 r., ponieważ w korespondencji do niewiadomego adresata $€$. Miaskowski wspomniał o znacznej renowacji murów obronnych, okrzesaniu skał, a także o przybyciu do Kamieńca posiłków złożonych z kilku setek okolicznej szlachty, która przyprowadziła ze sobą również artylerię ${ }^{35}$.

$\mathrm{Na}$ morale obrońców twierdzy kamienieckiej miały duży wpływ również czynniki psychologiczne, związane zarówno z zagrożeniem ze strony Tatarów, nieuchronnie nadciągającą ofensywą oddziałów pułkownika czerkaskiego M. Krzywonosa, jak i z obawą o zdradę ze strony przebywających w mieście oraz sprawujących służbę w kamienieckim garnizonie Rusinów.

Korespondencja $€$. Miaskowskiego pokazuje brak zaufania wobec przebywających w mieście wyznawców prawosławia. Jedną z prawdopodobnych przyczyn takiego stosunku sędziego podolskiego mogło być przejście ludności lokalnej na stronę Kozaków w trakcie oblężenia Baru ${ }^{36}$. Łukasz Miaskowski mógł mieć

28 LNNB, Z Kamieńca od pewnej osoby, fond 5, rkps 225, k. 124.

29 LNNB, Copia listu od JMP Łukasza Miaskowskiego sędziego podolskiego do JMP Wojciecha Miaskowskiego, podkomorzego lwowskiego, 15 VIII 1648, fond 5, rkps 225, k. 129.

30 LNNB, Z Kamieńca od pewnej osoby, fond 5, rkps 225, k. 124.

31 LNNB, Z Kamieńca do JMCi Pana podkomorzego lwowskiego, 17 VIII 1648, fond 5, rkps 225, k. $124 \mathrm{v}$.

32 Ibidem.

33 Ibidem.

${ }^{34}$ LNNB, Z Kamieńca, 18 VIII 1648, fond 5, rkps 225, k. 131.

35 Dizereta..., s. 131.

36 LNNB, Kopia listu od JMP Łukasza Miaskowskiego sędziego podolskiego do JMP Wojciecha Miaskowskiego, podkomorzego lwowskiego, 15 VIII 1648, fond 5, rkps 225, k. 128v. 
powody do obaw. Według doniesień lokalnych urzędników przed 15 sierpnia 1648 r. w Kamieńcu Podolskim przebywało około 5 tys. Rusinów, a w broniącym miasta garnizonie żołnierze tej narodowości stanowili 70 procent $^{37}$. Według Ł. Miaskowskiego zdrady obawiano się też ze strony wysłanych na podjazd żołnierzy, którzy zamiast patrolować okolicę, skupili się bardziej na rabowaniu okolicznej ludności, jawnego zaś przejścia na stronę wroga dokonał jeden ze szlacheckich sług kasztelana halickiego Stanisława Lanckorońskiego ${ }^{38}$. Warto dodać, że etnicznie polscy obrońcy twierdzy kamienieckiej aktywnie usiłowali kontrolować żywioł ruski. W tym celu Polacy „pomieszali między siebie Ruś i Ormiany"39, co było i narzędziem kontroli, i formą ochrony w razie zdobycia Kamieńca przez wojska kozackie. Sytuacja z lata 1648 r. była prawdopodobnie jedną z przyczyn ogłoszenia wspomnianej wyżej konstytucji z 1649 r., w której zakazano służby w garnizonie kamienieckim Rusinom.

Doniesienia o niebezpieczeństwie ze strony Ordy odnaleźć można już w liście z 4 lipca. Łukasz Miaskowski przekazał kanclerzowi Ossolińskiemu pozyskane od mołdawskich dostojników informacje o planowanej inkursji ordy krymskiej i dobrudzkiej na ziemie Rzeczypospolitej, jednak nie był on pewien szlaku, jaki obiorą Tatarzy $^{40}$. Także w korespondencji z sierpnia były wieści o planowanych działaniach tatarskich, a niepokój z tym związany wzrastał. W korespondencji z 9 sierpnia Ł. Miaskowski zaznaczył, że w obliczu działań Ordy Krymskiej, „która Dniepr przeszła, jeno nie wie, którym szlakiem”, hospodar mołdawski Bazyli Lupul zadecydował o pospiesznej ewakuacji kupców greckich i ormiańskich z Kamieńca Podolskiego ${ }^{41}$.

Sędzia podolski nie polegał wyłącznie na informacjach uzyskanych od Mołdawian, ale organizował również działania płytkiego wywiadu, mające na celu rozeznanie poczynań przeciwnika ${ }^{42}$. W kolejnym liście, tym razem adresowanym do chorążego koronnego Aleksandra Koniecpolskiego, Ł. Miaskowski doniósł, że w wyprawie na tereny Rzeczypospolitej weźmie udział również orda budziacka, najazd zaś przebiegnie albo szlakiem czarnym, albo kuczmańskim ${ }^{43}$.

37 Ibidem, k. 129.

38 Ibidem.

39 Díereta..., s. 130.

40 LNNB, Z Kamieńca 4 VII 1648, fond 5, rkps 225, k. 88.

41 LNNB, Z Kamieńca 9 VIII 1648, fond 5, rkps 225, k. 120.

42 LNNB, Z Kamieńca do JMP Sieniawskiego, 10 VIII 1648, fond 5, rkps 225, k. 121.

43 LNNB, Z Kamieńca do JMci Pana chorążego koronnego, 12 VIII 1648, fond 5, rkps 225, k. $123 \mathrm{v}-124$. 
Co ciekawe, w niemal całej dalszej części korespondencji sędziego podolskiego informacje o Tatarach nie występowały. Konkretne wiadomości pojawiły się dopiero w liście z 20 sierpnia 1648 r., w którym Ł. Miaskowski przekazał nieznanemu adresatowi informację uzyskaną od burkołaba chocimskiego Petryczejki. Według mołdawskiego dostojnika orda w rzeczywistości zamierzała najechać na Podole, jednak powstrzymała ją interwencja urzędników sułtańskich ${ }^{44}$.

Równie duże, jeśli nie większe emocje budziła w mieszkańcach Kamieńca Podolskiego groźba ataku ze strony Kozaków. Po wyjątkowo brutalnym zdobyciu Baru przez wojska dowodzone przez M. Krzywonosa do Kamieńca przybywali kolejni uratowani z rzezi mieszkańcy tego miasta, którzy ujawniali nowe szczegóły kozackiego szturmu. Te informacje, wraz z doniesieniami o działaniach oddziałów nieprzyjaciela znajdujących się w okolicach Zinkowa ${ }^{45}$ oraz Medoboru $^{46}$, prawdopodobnie mocno wpłynęły na morale przebywających w Kamieńcu, a przynajmniej na stan psychiczny Ł. Miaskowskiego i jego rodziny. Znamienne jest, że w większości korespondencji z omawianego okresu nadawca zawarł jednoznaczne prośby o ratunek - np. w liście z 9 sierpnia Ł. Miaskowski apelował do niewiadomego adresata: „Na Boga, ratujcie WM choć mury i kościoły, kiedy nas Braci nie chcecie” ${ }^{\text {”7 }}$. W strachu żyła też rodzina Ł. Miaskowskiego, który w liście do brata pisał: „Dla ustawicznych we dnie i w nocy lamentów moich Białych głów niewypowiedzianie jestem frasobliwy..."’38. Tak silne poczucie zagrożenia obrońców twierdzy zmniejszyło się, gdy około 20 sierpnia 1648 r. do Kamieńca dostarczono informacje o rzeczywistych rozmiarach kozackiej ofensywy. Zamiast dwóch, o których sędzia podolski pisał we wcześniejszej korespondencji ${ }^{49}$, bądź też sześciu pułków, przyczyną zamieszania okazało się sześć chorągwi „podniestrskiego chłopstwa”, które plądrowały podolskie wsie i miasteczka, rabowały bydło oraz mordowały Polaków ${ }^{50}$. Obrońcy

${ }^{44}$ Dżereta..., s. 130-131.

45 LNNB, Z Kamieńca od pewnej osoby, fond 5, rkps 225, k. 124; LNNB, Z Kamieńca do JMci Pana chorążego koronnego, 12 VIII 1648, fond 5, rkps 225, k. $123 \mathrm{v}$.

46 LNNB, Copia listu od JMP Łukasza Miaskowskiego sędziego podolskiego do JMP Wojciecha Miaskowskiego, podkomorzego lwowskiego, 15 VIII 1648, fond 5, rkps 225, k. 129v ; Dżereta..., s. 130 .

47 LNNB, Z Kamieńca 9 VIII 1648, fond 5, rkps 225, k. 120.

48 LNNB, Z Kamieńca do JMCi Pana podkomorzego lwowskiego, 17 VIII 1648, fond 5, rkps 225, k. $124 \mathrm{v}$.

49 LNNB, Z Kamieńca od pewnej osoby LMSP, fond 5, rkps 225, k. 124.

50 Dizereta..., s. 130. 
Kamieńca, według słów Ł. Miaskowskiego, planowali opuścić twierdzę, jednak obietnice wsparcia ze strony wojewodów: kijowskiego Janusza Tyszkiewicza, ruskiego Jeremiego Wiśniowieckiego, podolskiego Stanisława Rewery Potockiego oraz przybycie do miasta okolicznej szlachty zmotywowały ich do naprawy umocnień ${ }^{51}$.

Wymienione powyżej czynniki wyraźnie wskazują na brak jakiegokolwiek przygotowania Kamieńca Podolskiego do przyjęcia kozackiego oblężenia. Stan umocnień był dalece niezadowalający, nieliczna załoga nie wystarczała do obsadzenia całej długości murów, brakowało ołowiu, prochu oraz wyszkolonych artylerzystów. Również dowodzący obroną twierdzy kasztelan halicki Stanisław Lanckoroński wykazał się niekompetencją w werbowaniu oddziałów posiłkowych do obrony twierdzy. Obrońcy obawiali się zdrady ze strony przebywających w mieście Rusinów, najazdu dużych sił tatarskich oraz podzielenia losu Baru, zdobytego przez wojska kozackie. Ze względu na brak większej liczby relacji innych osób przebywających wówczas w Kamieńcu Podolskim nie sposób dociec, czy przedstawione wcześniej w tekście obawy Ł. Miaskowskiego podzielali też inni Polacy. Udało się odnaleźć jeden list datowany na lato 1648 r., którego autorka, szlachcianka Zuzanna Jarmolińska, informuje swoją nieznaną z nazwiska odbiorczynię o sytuacji i nastrojach w mieście:

że co godzina teo nieprzyjaciela pod Kamieńcem wyglądamy, którzy już wszystkie majętności w. m. i nasze opanowali, pasieki powybierali, bydła pobrali i moje, które $\mathrm{w}(. . .)^{*}$ było i prawie wszystko wniwecz obrócili. Oto tylko Boga prosimy, abyśmy się sami w Kamieńcu przy zdrowiu zostali, tymże ciesząc, że w Bogu Samym nadzieje położyliśmy, wże i ludzie dobrych siła do obrony miasta i ludzie pana chorążego koronnego ${ }^{52}$ stoją kilka tylko mil od Kamieńca. Obywatele kamienieckie posyłali do ks. jeo m. Wisznioweckiego i pana chorążego koronnego, prosząc o posiłki Kamieńcowi z tym że opowiadając, że jeżeli posiłków nie dadzą, ustępują taborem z Kamieńca, bo ledwie książę pana chorążego koronnego uprosili i pana wojewodę podolskiego i pana starostę bracławskiego, że na tych dniach mają przyjść pod Kamieniec ${ }^{53}$.

Można więc uznać, że strach przed kozackim oblężeniem nie dotyczył wyłącznie Ł. Miaskowskiego, ale także innych osób przebywających wówczas

\footnotetext{
51 Ibidem, s. 130-131.

52 Aleksander Koniecpolski.

53 Díereta..., s. 56.
} 
w twierdzy. Co interesujące, informacje o gotowości Kamieńca do przyjęcia nieprzyjacielskiego szturmu dość szybko rozpowszechniły się po Rzeczypospolitej. Zarówno w liście szlachcica Piotra Trzybałkowskiego z 16 sierpnia 1648 r. ${ }^{54}$, jak i w anonimowej korespondencji z 21 sierpnia 1648 r. ${ }^{55}$ podniesiono kwestię umacniania podolskiej twierdzy. Ze względu na późny okres powstania obu listów można jednak przypuszczać, że odzyskanie ducha bojowego oraz poprawa morale obrońców Kamieńca nie zostały przegapione przez ówczesną opinię publiczną.

$\mathrm{Na}$ sam koniec warto postawić pytanie - czy oblężenie Kamieńca Podolskiego w 1648 r. rzeczywiście doszło do skutku? Według ustaleń Walerija Stepankowa oraz Walerija Smolija Kamieniec Podolski pod koniec sierpnia tego roku oblężony został przez liczące około 10 tys. ludzi oddziały „opryszków”56. Siły te stały pod twierdzą do początków grudnia 1648 r., jednak wtedy, jak i przez cały okres powstania Chmielnickiego pozostała ona niezdobyta.

\section{BIBLIOGRAFIA}

\section{Źródła archiwalne}

Archiwum Narodowe w Krakowie

Zbiór Rusieckich: 41.

Biblioteka im. ks. Czartoryskich w Krakowie 379, 1577.

Biblioteka Polskiej Akademii Nauk i Polskiej Akademii Umiejętności w Krakowie Teki Michałowskiego, 2254.

Lwowska Narodowa Naukowa Biblioteka im. Wasyla Stefanyka we Lwowie Fond 5, 225.

\footnotetext{
${ }^{54}$ Ibidem, s. 123.

55 Ibidem, s. 133.

56 В. СмолІй, В. СТеПАнков, Українська національна революиія XVII столітmя (16481676), Київ 2009, s. 90. Więcej o działaniach wojsk kozackich w opisywanym okresie vide: I. GAVRYLIUK, Niewygrana wojna. Sztuka wojenna Bohdana Chmielnickiego i innych dowódców kozackich w latach 1648-1651, Oświęcim 2019, s. 82-106.
} 


\section{Starodruki}

Miaskowski Ł., Rosprawa Jaśnie Wielmożnego Pana J.Mści P. Stanistawa z Koniecpola Koniecpolskiego, Woiewody Sendomirskiego, Hetmana Koronnego, etc, etc, z Woyjskiem Xiążcia Sudermańskiego Gustawa pod Amerstynem, w R. P. 1627, d. 17 kwietnia, Warszawa 1627.

\section{Źródła drukowane}

Documente privitoare la istoria Romanei culnese din arbivele polone. Secoul al XVII-lea, red.

I. Corfus, Bukareszt 1983.

Dżereta z istoriji Nacional'no-wyzwol'noji wijny ukrajins'koho narodu, t. 1, wyd. J. Mycyk, Kijów 2011.

Jakuba Michatowskiego, wojskiego lubelskiego a póżniej kasztelana bieckiego ksiega pamiętni$c z a$, red. A. Helcel, Kraków 1864.

Korespondencja Stanistawa Koniecpolskiego, hetmana wielkiego koronnego, red. A. Biedrzycka, Kraków 2005.

Pamiętniki o Koniecpolskich, wyd. S. Przyłęcki, Lwów 1842.

Volumina Legum, t. 2, wyd. J. Ohryzko, Petersburg 1859.

Volumina Legum, t. 4, wyd. J. Ohryzko, Petersburg 1859.

\section{Opracowania}

Dybaś B., Fortece Rzeczypospolitej. Studium z dziejów budowy fortyfikacji statych w państwie polsko-litewskim w XVII wieku, Toruń 2018.

Gavryliuk I., Niewygrana wojna. Sztuka wojenna Bohdana Chmielnickiego i innych dowódców kozackich w latach 1648-1651, Oświęcim 2019.

Hundert Z., Garnizon wojskowy Kamieńca Podolskiego w latach 1668-1672, „Saeculum Christianum" 2014, t. 21, s. 141-153.

Kamieniec Podolski. Studia z dziejów miasta i regionu, t. 1, red. F. Kiryk, Kraków 2000.

Kamieniec Podolski. Studia z dziejów miasta i regionu, t. 2, red. F. Kiryk, Kraków 2005.

Kołodziejczyk D., Podole pod panowaniem tureckim. Ejalet kamieniecki 1672-1699, Warszawa 1994.

Król-Mazur R., Miasto trzech nacji. Studia z dziejów Kamieńca Podolskiego w XVIII wieku, Kraków 2008.

Milewski D., Rywalizacja polsko-kozacka o Motdawię w dobie powstania Bohdana Chmielnickiego (1648-1653), Zabrze 2011. 
Nagielski M., Piotr Potocki, wojewoda bractawski - Hektor kamieniecki, „Wieki Stare i Nowe" 2020, t. 15 (20), s. 42-60.

Nowak T.M., Fortyfikacje i artyleria Kamieńca Podolskiego w XVIII w., „Studia i Materiały do Historii Wojskowości” 1973, t. 19, s. 139-186.

Nowak T.M., Polska artyleria, inżynieria i kartografia wojskowa $w$ XVII wieku, „Studia i Materiały do Historii Wojskowości” 1979, t. 22, s. 65-130.

Nowak T.M., Twierdza Kamieniec Podolski $w$ XVIII w. na tle polskiej fortyfikacji na ziemiach zagrożonych najazdami Turków i Tatarów, „Fortyfikacja” 1995, t. 1, s. 25-36.

Oprychał L., Plany Kamieńca Podolskiego w bibliotekach i archiwach świata, „Kwartalnik Historii Nauki i Techniki” 2016, R. 61 (2), s. 89-110.

Oprychał L., Rękopiśmienne plany i ryciny twierdzy Kamieniec Podolski, Warszawa 2019.

Urzędnicy podolscy XIV-XVIII wieku: spisy, red. A. Gąsiorowski, Kórnik 1998.

Witusik A.A., Korespondencja jeńców cecorskich, „Rocznik Lubelski” 1987-1988, R. 29-30, s. 109-112.

Witusik A.A., Miaskowski Łukasz Kazimierz h. Leliwa, [w:] Polski Stownik Biograficzny 1975 , t. 20, z. 86 , s. 544-545.

Смолій В., Степанков В., Украӥнська національна револючія XVII столітmя (16481676), Київ 2009 (Smolij W., Stepankow W., Ukrajins'ka nacional'na rewolucija XVII st. (1648-1676 rr.), Kijów 2009).

Izabela Śliwińska-Słomska

\section{THE INTERNAL SITUATION OF KAMIANETS-PODILSKYI IN THE SUMMER OF 1648 IN THE CORRESPONDENCE OF ŁUKASZ MIASKOWSKI, THE PODOLIA DISTRICT JUDGE}

Summary. Łukasz Miaskowski, a Podolia District Judge and Marshal of the Podolia Hood Court during the interregnum after the death of Władysław IV, was in the summer of 1648 in Kamianets-Podilskyi. Due to his extensive contacts with the elite of the Principality of Moldavia, he obtained, aggregated and passed on to the elites of the Polish- Lithuanian Commonwealth information about events that took place in the Danubian principalities, the movements of the Tatar troops or the internal situation in the Ottoman Empire. In the summer of 1648, in the first period of Khmelnytsky's Uprising, he also reported on the progress in the offensive of the Cossack troops, the mood among the rural population of Podolia and the Ukrainian lands, and the internal situation of Kamianets-Podilskyi. The analysis of the sources included in the article shows the technical condition of the fortress, the number of its crew and factors impacting the morale of its defenders, such as: fear of attack by the Cossacks and Tatars and fear of betrayal by the Ruthenians staying in the city. The addressees of Miaskowski's correspondence include Grand Chancellor of the Crown Jerzy Ossoliński, Grand Standard-Bearer of the Crown Aleksander Koniecpolski, Crown Field Clerk Adam Hieronim Sieniawski or Lviv Chamberlain, and privately the sender's brother, Wojciech Miaskowski.

Keywords: Kamianets-Podilskyi, Khmelnytsky's Uprising, Siege, Łukasz Miaskowski, Cossacks 